\title{
187 Surgical treatment of vasomotor rhinitis
}

A Is necessary in the majority of cases.

$B$ Headache is an indication for diathermy to the middle turbinates.

C Septal surgery may be helpful even if the cartilaginous deformity is minor.

D Reduction of the inferior turbinates is an out-patient procedure.

E Long term cure is to be expected.

\section{Aetiology of allergic rhinitis}

A It is often familial.

$B \quad \lg E$ is the reaginic antibody.

C Co-existing asthma or eczema implies atopy.

D Inhaled allergens are the commonest trigger factor.

E Aspirin gives relief by reducing the inflammatory reaction.

\section{Immunology of allergic rhinitis}
A Most patients have a specific allergy to one substance only.
B IgE is released by the mast cell.
C There is a Type I hypersensitivity reaction.
D Histamine leaks from the endothelial cells via loosened desmosomal junctions.
E IgG is involved in some cases. 